\title{
O FRAGMENTARYZACJI SREBRA WCZESNOŚREDNIOWIECZNEGO: NA ILE WIARYGODNE SA DANE METROLOGICZNE? PRZYPADEK SKARBU Z MÓZGOWA NA WARMII (T.P.Q. 1009) ${ }^{1}$
}

\author{
FRAGMENTED EARLY MEDIEVAL SILVER: \\ HOW RELIABLE ARE METROLOGICAL DATA? \\ THE CASE OF THE TREASURE FROM MÓZGOWO IN WARMIA (T.P.Q. 1009)
}

\begin{abstract}
For years, a discussion has been held about the circulation of silver in the early Middle Ages and the role played by fragments of coins and ornaments. This multi-faceted discussion has also revolved around the function of the smallest fragments. Metrological research has indicated certain regularities in the incidence of fragments of a specified weight depending on region and chronology. New data for this discussion was provided by a treasure trove originally discovered in 1868 in Mózgowo in Warmia. Only slightly more than 400 coins have survived from the items discovered in the $19^{\text {th }}$ century; they are a part of a collection of the Herzog Anton Ulrich Museum in Braunschweig. The place where the treasure was discovered was identified in 2010; more than 800 coins and fragments thereof were unearthed. In 2012, the area was examined as a site of excavation where subsequently over 370 specimens were discovered. The treasure trove must have been hidden sometime after 1009, most probably around 1015. The coins from the museum in Braunschweig are not suitable for metrological analysis because they were intentionally separated for a systematic collection. Following an analysis of the specimens discovered in 2010 and 2012, considerable discrepancies in weight frequencies were observed. It turns out that in the collection of objects excavated by professional metal detector operators, very small fragments of silver prevail. Before, they were rarely registered in early medieval treasures (fragments weighing more than 1 gram represent only $6.66 \%$, pieces weighing less than $1 \mathrm{~g}$ represent $93.33 \%$, fragments of up to $0.5 \mathrm{~g}$ represent $87.61 \%$, while pieces weighing less than $0.1 \mathrm{~g}$ represent a whopping $55 \%$ of the entire collection).
\end{abstract}

* ORCID: 0000-0001-8810-8785; Instytut Archeologii i Etnologii PAN - Ośrodek Interdyscyplinarnych Badań Archeologicznych, Al. Solidarności 105, 00-140 Warszawa, e-mail: matbogu@yahoo. com.

${ }^{1}$ Tekst ten jest poprawioną i rozszerzoną o komentarz częścią opracowania skarbu z Mózgowa, które ukazało się już drukiem (Bogucki, Ilisch i Kulesza 2013, s. 14-139). Ponieważ monografia ta ukazała się bez opracowania redakcyjnego i bez korekt, a sama publikacja jest bardzo trudno dostępna, natomiast wnioski wypływające $\mathrm{z}$ analizy skarbu wydają się istotne, uznałem, że warto je zaprezentować szerszemu gronu czytelników. Ukazała się również wersja angielskojęzyczna niniejszego tekstu (Bogucki 2018, s. 57-72). 
The differences in the weight of silver fragments in the specific parts of the treasure trove from Mózgowo shed new light on both the methodology of examining treasure troves and how representative the data used so far in statistical and metrological analyses are.

Keywords: Poland, Viking-Age, Hoards, Coin Circulation, Hacksilver, Metrology.

\section{FRAGMENTARYZACJA SREBRA W POLSCE WCZESNOŚREDNIOWIECZNEJ}

Dzielenie monet i przedmiotów srebrnych na mniejsze fragmenty jest jedną z cech charakterystycznych dla znalezisk monet i ozdób dla okresu wczesnego średniowiecza w Europie. Dzielenie srebra odnotowane jest w całym świecie wikińskim - od Irlandii po Ruś. Nie bez przyczyny znaleziska gromadne tego rodzaju określane są jako skarby „siekańcowe”. Oczywiście, tak zdefiniowane znaleziska wykazują zróżnicowanie chronologiczne i terytorialne. Skarby te interpretowane są powszechnie jako ukryte zasoby pieniężne, ich kawałkowanie zaś jako efekt długiego obiegu na rynkach i potrzeby używania w codziennych, niewielkich transakcjach (Kiersnowski 1960; Hårdh 1996). W niniejszym szkicu, obok skróconego przedstawienia tego zjawiska na przykładzie ziem polskich, postaram się zwrócić uwagę na nieco inny aspekt badań nad fragmentaryzacją srebra we wczesnym średniowieczu - w jakim stopniu nasze dane dotyczące fragmentaryzacji srebra są reprezentatywne?

$\mathrm{Na}$ ziemiach polskich fragmentryzację srebra można zaobserwować już w początkach IX wieku. Siekańce dirhemów arabskich z tego czasu odnajdywane są niemal wyłącznie w emporium Truso (Bogucki 2007, s. 79-108) i w niewielkiej liczbie na zaledwie kilku stanowiskach na Pomorzu Zachodnim - głównie w okolicach Kołobrzegu (Łosiński 1998, s. 93-181). Do połowy X w. fragmentaryzacja srebra, choć występuje, to notowana jest raczej sporadycznie. Zjawisko to występuje najczęściej w znaleziskach datowanych od około 970/80 do około 1020 roku (por. Bogucki 2011, s. 135-138, tam starsza literatura).

W literaturze polskiej istnieje kilka koncepcji, próbujących objaśnić zjawisko fragmentaryzacji srebra we wczesnym średniowieczu. Ponieważ były one już prezentowane i dyskutowane zarówno w literaturze polskiej, jak i zagranicznej, ograniczę się tylko do ich wyszczególnienia:

- srebro orientalne mogło być dzielone jeszcze na obszarach rodzimych i dotarło nad Bałtyk już pokawałkowane (Ilisch 1990, s. 121-131);

- wytworzenie jednostek pieniężnych o niewielkiej wartości przyjmowanych na sztuki (Kiersnowski 1960; Suchodolski 2004, s. 107-116; 2013, s. 89-107);

- wytworzenie fragmentów o niewielkiej wadze, przeznaczonych do odważania (Suchodolski 2004, s. 107-116; 2013, s. 89-107; Bogucki 2011, s. 140-145);

- dzielenie srebra ze względów kultowych i rytualnych (Duczko 2002, s. 193-208; Urbańczyk 2002, s. 209-224; 2009, s. 501-523).

Podejmując dyskusję nad fragmentaryzacją srebra, część autorów (w tym i niżej podpisany - Bogucki 2004, s. 49-76; 2005, s. 1151-1157) błędnie traktowała za- 
równo dzielenie na kawałki, jak i nacinanie (pecks, nicks) jako przejaw tego samego lub bardzo podobnego zjawiska. Obecnie sądzę, że w zasadniczej części oba te zwyczaje były powodowane różnymi pobudkami i należy je rozdzielić i interpretować osobno. Oczywiście mogły i zapewne przenikały się wzajemnie, jednak ich główne przyczyny miały różny charakter. O ile fragmentaryzacje jestem skłonny widzieć głównie jako działanie o podłożu ekonomicznym - wytworzenie fragmentów o niewielkiej wadze, przeznaczonych do odważania, o tyle nacinanie, gięcie, młotkowanie i ogólne dręczenie srebra miało zapewne podłoże pozaekonomiczne - zwyczajowo-rytulano-magiczne (Bogucki 2011, s. 140-145).

\section{W POSZUKIWANIU MAŁEJ JEDNOSTKI...}

Przyjęcie założenia, że fragmentaryzacja była spowodowana potrzebą wytworzenia fragmentów o niewielkiej wadze, przeznaczonych do odważania, powoduje, że w dostępnym materiale można próbować wyszukać pewne prawidłowości metrologiczne. Próby takie podejmowane były już od dawna. Przede wszystkim szukano najmniejszej jednostki wagowej, która pokazywałaby, jaka waga srebra siekanego była najpowszechniej używana w codziennych transakcjach (Kiersnowski 1960; Suchodolski 1971, s. 503-515; 2012, s. 135-139; Bogucki 2004, s. 61-62).

W skarbach z Pomorza, Wielkopolski i Mazowsza z okresu od około 970 do około 1020 r. można wyróżnić dwie dominujące wagowo grupy fragmentów (tabela 1):

Tabela 1. Wagi dwóch dominujących grup fragmentów srebrnych siekańców w poszczególnych dzielnicach

\begin{tabular}{|l|c|c|c|}
\hline & Pomorze & Wielkopolska & Mazowsze \\
\hline Pierwsza mała jednostka & $0.3-0.4$ & $0.2-0.3$ & $0.1-0.2$ \\
\hline Druga mała jednostka & $0.7-0.8$ & $0.6-0.7$ & $0.5-0.6$ \\
\hline
\end{tabular}

Łatwo zauważyć, że im dalej na południowy wschód, tym waga najczęściej występujących fragmentów srebra maleje. Warto przy tym podkreślić, że fragmenty monet i srebra w Skandynawii są jeszcze cięższe, zatem zmniejszanie się wagi w kierunku południowo-wschodnim (w ramach strefy nadbałtyckiej) wydaje się mieć silne podstawy (Tambor 1989, s. 16-24; Hårdh 1996, s. 84-130; Nowakiewicz 2003, s. 81-285; Bogucki 2004, s. 62). Pomijając zróżnicowanie lokalne, wynikające z dostępności kruszcu, dla Polski wczesnośredniowiecznej przyjęto, że $0.2 \mathrm{~g}$ srebra było na przełomie X i XI w. miarą podstawową w codziennych rozliczeniach. Oprócz wyliczeń statystycznych, waga ta ma potwierdzenie w dwóch innych rodzajach źródeł. Warto zwrócić uwagę, że duńskie półbrakteaty z tego okresu 
(typy KG 9-12), produkowane na rynek lokalny, ważą średnio około 0.15-0.5 g (Malmer 1966; Suchodolski 2013, s. 89-107). Tak zwane odmiany „krzyżowe”, z końca X w., ważą średnio 0.2-0.35 g (Moesgaard 2015, s. 45), co współgra $\mathrm{z}$ najliczniejszą wagą fragmentów srebra ze znalezisk polskich. Ponadto istnieje wsparcie w źródłach pisanych - Ibrahim ibn Jakub zanotował w latach 60 . X w., że w czeskiej Pradze za jednego kinšar/kirat (denar europejski), można było nabyć 10 kurczaków lub pszenicy dla jednego człowieka na miesiąc, lub jęczmień dla konia na 40 nocy (Kowalski 1946). $Z$ danych tych można łatwo wyliczyć, że jeden kurczak kosztował 1/10 denara, a więc około 0.15-0.2 g srebra (Bogucki 2004, s. 61-62). Przedstawione powyżej dane źródłowe pokazują jasno, że około $0.2 \mathrm{~g}$ srebra stanowiło najczęściej używaną sumę w 2. połowie X i początkach XI wieku.

Pomimo że wyniki obliczeń statystycznych znajdują swoje odpowiedniki w metrologii wybranej grupy monet oraz znajdują pewne potwierdzenie w wymowie źródeł pisanych, to należy postawić pytanie o reprezentatywność bazy źródłowej - czyli odnotowanych wag fragmentów srebra pochodzących ze skarbów wczesnośredniowiecznych. Przyczynkiem do tych rozważań jest historia odkrywania skarbu z Mózgowa, która pokazuje, że nasza dotychczasowa podstawa źródłowa jest niekompletna. Wydaje się, że podobne analizy należałoby przeprowadzić w przypadku większej liczby „na nowo" odkrywanych skarbów, co w ostatnich latach ma coraz częstsze miejsce zarówno w Polsce, jak i w Skandynawii (główne na Gotlandii).

\section{SKARB Z MÓZGOWA (RYC. 1)}

Pierwszego odkrycia monet i ozdób wczesnośredniowiecznych nieopodal Mózgowa (gmina i powiat Iława, dawne Mosgau, Kreis Rosenberg) dokonano w październiku 1868 r. podczas orki na polu Benjamina Beyera z Kisielic (dawne Freystadt, Kreis Rosenberg). Już w tej pierwszej notatce zamieszczono informacje o wystąpieniu tam niemieckich monet cesarskich Ottona III i Henryka II, angielskich Ethelreda II i czeskich księcia Bolesława II. Zidentyfikowano wówczas monety z mennic w Kolonii, Strasburga i Augsburga i określono czas ukrycia depozytu na mniej więcej 1000 r. (Bergau 1868, s. 557). Ta część skarbu nie dostała się do żadnych zbiorów publicznych, zasilając kilka kolekcji prywatnych.

Nieco więcej dokładniejszych informacji podał niebawem Hermann Dannenberg (1876, s. 47), który miał możliwość zapoznania się z kolekcją niejakiego von Mülverstedta, dyrektora archiwum miejskiego w Magdeburgu, który posiadał około 2000 monet ze skarbu z Mózgowa. H. Dannenberg umieścił opis tej części skarbu w swoim wykazie pod numerem 11. Ze względu na źródłowy charakter tego opisu, przytoczymy go w całości: 
11) Mosgau (bei Rosenberg, West-Preussen ${ }^{1}$ ). [Ca. 1010]

a) Deutsche: Metz (Adalbero II, Theodorich II), Verdun (Haimo), Masstricht (Otto, Heinrich II), incert. Rf. Heinricus moneta, Thuin (? Mém. IV, S. 59), Viset (Otto III), Köln (Ottonen), Herzog Theodorich EIL CIV, Deventer (Otto) - Otto \& Adelheid, Herzog Bernhard (nur mit Kopf), Hildesheim (Otto, Bernward), Magdeburg, Halberstadt (Arnolf), Dortmund (Otto, Heinrich), Wendenpf. grosse und kleine (letztere Nachahmungen der Magdeburger) Schwaben Herzog Otto (?ac pacif.), Breisach (Otto), Esslingen, Strassburg (Otto, Heinrich II, B. Widerold), Basel (K. Konrad 937-993), Constanz, Augsburg (Liutolf, Siegfried, Bruno, nur vom älteren Typus) - Neuburg NIVVAN CIVITAS (König Heinrich II), Regensburg, ausser Otto auch Herzog Heinrich (985-995) und H. rex vom alten (Portal-) Typus, aber auch mit Kopf (Rf. VECCHO), Salzburg (Herzog Heinrich IV).

b) Böhmen, Boleslaw, Jaromir - Verona (Otto III) - Ethelred - Norwegen (Erik Jarl 10001015) - Bruchstücke von arabischen Dirhems.

Unter allen kein Konrad H., ja nicht einmal ein Heinrich 11. mit Kaisertitel, kein Ulrich von Böhmen (1012-1037) und kein Knut (1010-1035), auch kein Regensburger Heinrich V. mit dem Schriftkreuze. Wir kommen also etwa auf dieselbe Zeit wie bei den beiden vorigen Funden, höchstens vielleicht wegen des häufigeren Auftretens der Heinricus rex - Denare 1-2 Jahre später.

${ }^{1}$ Nach gefälliger Mittheulung des Hrn. Archivrats v. Mülverstedt in Magdeburg, dem dieser Fund grösstentheils zugefallen, betrug derselbe etwa 2000 Stück. Möglich, dass manches in der mir vorgelegten Auswahl gefehlt hat.

W drugim tomie swojego dzieła H. Dannenberg skorygował określenie jednej monety - denara Grafa Henryka ze Stade, którą pierwotnie przypisywał norweskiemu Jarlowi Erykowi (Dannenberg 1894, s. 521). Ponadto różne monety ze skarbu z Mózgowa były wzmiankowane w pracach Eduarda Fiali i kilku innych autorów, którzy powtarzali (czasami błędnie) informacje H. Dannenberga (Fiala 1891, s. 31, Nr 28; 1895, s. 161, Nr 29; Gumowski 1905, s. 62; 1953, s. 91; Markov 1910, s. 114; Chmielecki 1907, s. 36, Nr 8; Kujot 1913, s. 258; Suhle 1926, s. 82; Łęga 1930, s. 588, Nr 106; Langenheim 1933, s. 282, Nr 34; La Baume 1938, s. 53; Jammer 1952, s. 145, Nr 230; Albrecht 1959, s. 170, Nr 292; Żak 1963, Nr 132; Cach 1970, Nr 114; Gajewski 1982, s. 26; Kócka-Krenz 1993, s. 276; Ilisch 1998, s. 19, 109). Wyjątek stanowi niewielki artykuł E. Fiali z 1922 r., w którym opisuje on pochodzący ze skarbu z Mózgowa czeski denar Bolesława III, z imieniem mincerza JOHAN ETL, który wraz z wieloma denarami niemieckimi, kilkoma włoskimi, angielskimi i norweskimi, ułamkami dirhemów i kilkoma denarami Bolesława i Jaromira miał zostać zakupiony ,,przed wielu laty” przez niejakiego Vávra we Frankfurcie nad Menem (Fiala 1922, s. 181-182).

Do niedawna najbardziej aktualną wiedzą na temat tego skarbu był wykaz opublikowany w drugim tomie inwentarzy Polskie Skarby Wczesnośredniowieczne (Kiersnowscy 1959, s. 72-73, Nr 107), a losy monet pochodzących ze skarbu z Mózgowa były nieznane. Dopiero w latach 70. XX w. zidentyfikował je prof. Wolf- 
gang Hahn w Muzeum Księcia Antona Ulricha w Brunszwiku, a trzydzieści lat później wstępnie opisał prof. Borys Paszkiewicz. Wreszcie w 2013 r. dr Peter Ilisch określił wszystkie monety. W inwentarzach muzealnych zanotowano, że monety te zostały zakupione od niejakiego Mülverstedta z Magdeburga w 1902 roku. Odnotowano również, że druga część skarbu była w posiadaniu dyrektora gimnazjum Wiggerta, która następnie została sprzedana Emilowi Bahrfeldtowi ${ }^{2}$. Nie ma większych wątpliwości, że odnotowany w brunszwickich księgach inwentarzowych Mülverstedt to ta sama osoba, co wspomniany przez Dannenberga dyrektor archiwum miejskiego w Magdeburgu. Był nim Johan George Adalbert von Mülverstedt, urodzony w Gdańsku, uczęszczający do gimnazjum w Tylży i na uniwersytet w Królewcu. Interesował się nie tylko genealogią, która była głównym przedmiotem jego pracy, ale i numizmatyką - oprócz zbierania monet, w 1868 r. opublikował nawet pracę pt. Magdeburgisches Münzkabinett des neuen Zeitalters (Herfurth 1997, s. 516-517). Biorąc pod uwagę jego pochodzenie, wydaje się, że musiał mieć dobre kontakty wśród kolekcjonerów i handlarzy w Prusach Zachodnich i tą drogą nabył dużą część monet odkrytych w Mózgowie.

Johan von Mülverstedt zmarł w 1914 r., stąd jest niemal pewne, że ,wiele denarów niemieckich, kilka włoskich, angielskich i norweskich, ułamki dirhemów i kilka denarów Bolesława i Jaromira" wraz z denarem JOHAN ETL, które według E. Fiali miały zostać zakupione ,przed wielu laty” przez Vávra, pochodziły z kolekcji J.G.A. von Mülverstedta (część należąca do dyrektora gimnazjum Wiggerta została sprzedana zapewne przed rokiem 1902 do kolekcji Emila Bahrfledta, która następnie została rozprzedana dopiero w 1921 roku). Z faktu, że Muzeum w Brunszwiku zachowało się tylko 426 monet ze skarbu z Mózgowa oraz z rozprzedania przez J.G.A. von Mülverstedta monet w różne miejsca wynika, iż porównanie monet brunszwickich $\mathrm{z}$ wykazem Dannenberga nie może być w pełni zgodne (tabela 2$)^{3}$.

\footnotetext{
${ }^{2}$ List kierownika gabinetu numizmatycznego w Muzeum Księcia Antona Ulricha w Brunszwiku, profesora Wolfganga Leschhorna z 2013 r.: „Teile des Fundes sind im Jahre 1902 von einem Herrn von Mülverstedt aus Magdeburg angekauft worden. Der Vorname des Verkäufers ist uns nicht mehr bekannt. Ich finde in unserem Inventarbuch den Hinweis, dass die zweite Hälfte des Fundes von Mosgau zunächst bei Gymnasialdirektor Wiggert lag, dann an S. Bahrfeldt ging. Die arabischen Münzen sollen 1902 an einen Herrn German in Niederlössnitz gegangen sein. Das Herzog Anton Ulrich-Museum gab eine Reihe angelsächischer Münzen Ethelreds ab und einen Denar Arnulfs von Halberstadt".

${ }^{3}$ Pewnym problemem $\mathrm{w}$ identyfikacji monet pochodzących ze skarbu z Mózgowa $\mathrm{w}$ zbiorach Muzeum w Brunszwiku jest fakt, że muzeum to posiada liczny zbiór denarów z X i XI w., w tym również z innych depozytów z obszaru Polski. Dowodnie udało się zidentyfikować co najmniej 31 monet pochodzących ze skarbu z Lisówka. Trafiły one tutaj wraz z częścią rozprzedanej kolekcji Emila Bahrfeldta (1921). Ponadto w Brunszwiku znajdują się monety wczesnośredniowieczne, których charakter wskazuje na pochodzenie z jakichś skarbów polskich lub wschodnioniemieckich. Dostały sie one tam wraz z cześsią sprzedanej kolekcji z zamku Friedenstein w Gotha, gdzie gromadzono monety przynajmniej od XVIII wieku (Eberle 2012). Pomimo tych wszystkich zastrzeżeń, należy stwierdzić, że prezentowane niżej monety stanowią reprezentatywną próbkę odkrytego w $1868 \mathrm{r}$. skarbu z Mózgowa.
} 
Tabela 2. Porównanie składu różnych części skarbu z Mózgowa oraz zsumowanie wszystkich znanych elementów

\begin{tabular}{|c|c|c|c|c|c|c|c|}
\hline Państwo & Region & Mennica & Literatura & Brunszwik & 2010 & 2012 & SUMA \\
\hline Kalifat & & & $X^{4}$ & 2 & 196 & 84 & $282+X$ \\
\hline \multirow{27}{*}{ Niemcy } & \multirow{6}{*}{$\begin{array}{c}\text { Górna } \\
\text { Lotaryn- } \\
\text { gia }\end{array}$} & Remiremont & & 2 & 1 & - & 3 \\
\hline & & Verdun & $\mathrm{X}$ & 4 & - & - & $4+X$ \\
\hline & & Toul & & 1 & - & - & 1 \\
\hline & & Metz & $\mathrm{X}$ & 2 & - & - & $2+X$ \\
\hline & & „Eyl” & $\mathrm{X}$ & 1 & - & - & $1+\mathrm{X}$ \\
\hline & & Górna Lotaryngia & & 1 & - & - & 1 \\
\hline & \multirow{12}{*}{$\begin{array}{c}\text { Dolna } \\
\text { Lotaryn- } \\
\text { gia }\end{array}$} & Tuin & $\mathrm{X}$ & 1 & - & - & $1+X$ \\
\hline & & Namur & & 1 & - & - & 1 \\
\hline & & Maastricht & $\mathrm{X}$ & 1 & - & - & $1+\mathrm{X}$ \\
\hline & & Ciney & & 1 & - & - & 1 \\
\hline & & Visé & $\mathrm{X}$ & 2 & - & - & $2+X$ \\
\hline & & Kolonia & $\mathrm{X}$ & 7 & 20 & 3 & $30+X$ \\
\hline & & Deventer & $\mathrm{X}$ & 8 & 3 & 1 & $12+X$ \\
\hline & & Hamaland & & 1 & 1 & - & 2 \\
\hline & & Boulogne? & & 1 & - & - & 1 \\
\hline & & $\begin{array}{l}\text { Zachodnia } \\
\text { Flandria }\end{array}$ & & 2 & - & - & 2 \\
\hline & & $\begin{array}{c}\text { Zachodnia Dolna } \\
\text { Lotaryngia }\end{array}$ & & 9 & - & - & 9 \\
\hline & & Niderlandy & & 5 & - & - & 5 \\
\hline & Fryzja & Fryzja & & 20 & 1 & - & 21 \\
\hline & \multirow{8}{*}{ Saksonia } & Dortmund & $\mathrm{X}$ & 7 & 3 & 1 & $11+X$ \\
\hline & & Soest & & 1 & - & - & 1 \\
\hline & & Münster & & 1 & - & - & 1 \\
\hline & & Stade & $\mathrm{X}$ & - & - & - & $\mathrm{X}$ \\
\hline & & Lüneburg & & 16 & 7 & - & 23 \\
\hline & & Hildesheim & $\mathrm{X}$ & - & - & - & $\mathrm{X}$ \\
\hline & & Otto \& Adelajda & $\mathrm{X}$ & 38 & 101 & 19 & $158+X$ \\
\hline & & Magdeburg & $\mathrm{X}$ & 1 & - & - & $1+\mathrm{X}$ \\
\hline
\end{tabular}

${ }^{4}$ „X” oznacza, że dany typ monety wystąpił, ale nie wiadomo, w jakiej liczbie. 


\begin{tabular}{|c|c|c|c|c|c|c|c|}
\hline & & Halberstadt & $\mathrm{X}$ & - & - & - & $\mathrm{X}$ \\
\hline & & Quedlinburg & & 4 & 1 & - & 5 \\
\hline & & Erfurt & & 4 & - & - & 4 \\
\hline & & Miśnia & & - & 1 & - & 1 \\
\hline & & Würzburg & & 6 & - & - & 6 \\
\hline & & Moguncja & & 32 & 7 & 1 & 40 \\
\hline & & Wormacja & & 10 & 3 & - & 13 \\
\hline & & Spira & & 2 & 7 & - & 9 \\
\hline & & Strassburg & $\mathrm{X}$ & 13 & 5 & - & $18+X$ \\
\hline & & Breisach & $\mathrm{X}$ & - & - & - & $\mathrm{X}$ \\
\hline & & Ulm & & 1 & - & - & 1 \\
\hline & & Esslingen & $\mathrm{X}$ & 4 & 1 & - & $5+X$ \\
\hline & & Bazylea & $\mathrm{X}$ & - & - & - & $\mathrm{X}$ \\
\hline & & Zürich & & 1 & - & 1 & 1 \\
\hline & & Konstancja & $\mathrm{X}$ & - & - & - & $X$ \\
\hline & & Augsburg & $\mathrm{X}$ & 12 & 2 & - & $14+X$ \\
\hline & & Ratyzbona & $\mathrm{X}$ & 32 & 4 & 1 & $37+X$ \\
\hline & & Freising & & 1 & - & - & 1 \\
\hline & Bawaria & Nabburg & & 4 & - & - & 4 \\
\hline & & Neuburg & $\mathrm{X}$ & - & - & - & $\mathrm{X}$ \\
\hline & & Salzburg & $\mathrm{X}$ & 2 & 2 & 2 & $6+X$ \\
\hline $\begin{array}{c}\text { Niemcy } \\
\text { - denary } \\
\text { krzyżówe }\end{array}$ & Saksonia & & & 44 & 102 & 43 & 189 \\
\hline Włochy & & & 1 & 4 & 1 & - & 6 \\
\hline Czechy & & & $\mathrm{X}$ & 30 & 39 & 16 & $85+X$ \\
\hline Węgry & & & & 1 & - & - & 1 \\
\hline Anglia & & & $\mathrm{X}$ & 31 & 39 & 22 & $92+X$ \\
\hline Dania & & & & 13 & 9 & 13 & 35 \\
\hline $\begin{array}{c}\text { Naśladownic- } \\
\text { twa }\end{array}$ & & & & 20 & - & - & 20 \\
\hline Nieokreślone & & & & 19 & 161 & 130 & 310 \\
\hline Ozdoby & & & 1 & - & 117 & 37 & 154 \\
\hline SUMA & & & & 426 & 834 & 374 & $1634+X$ \\
\hline
\end{tabular}




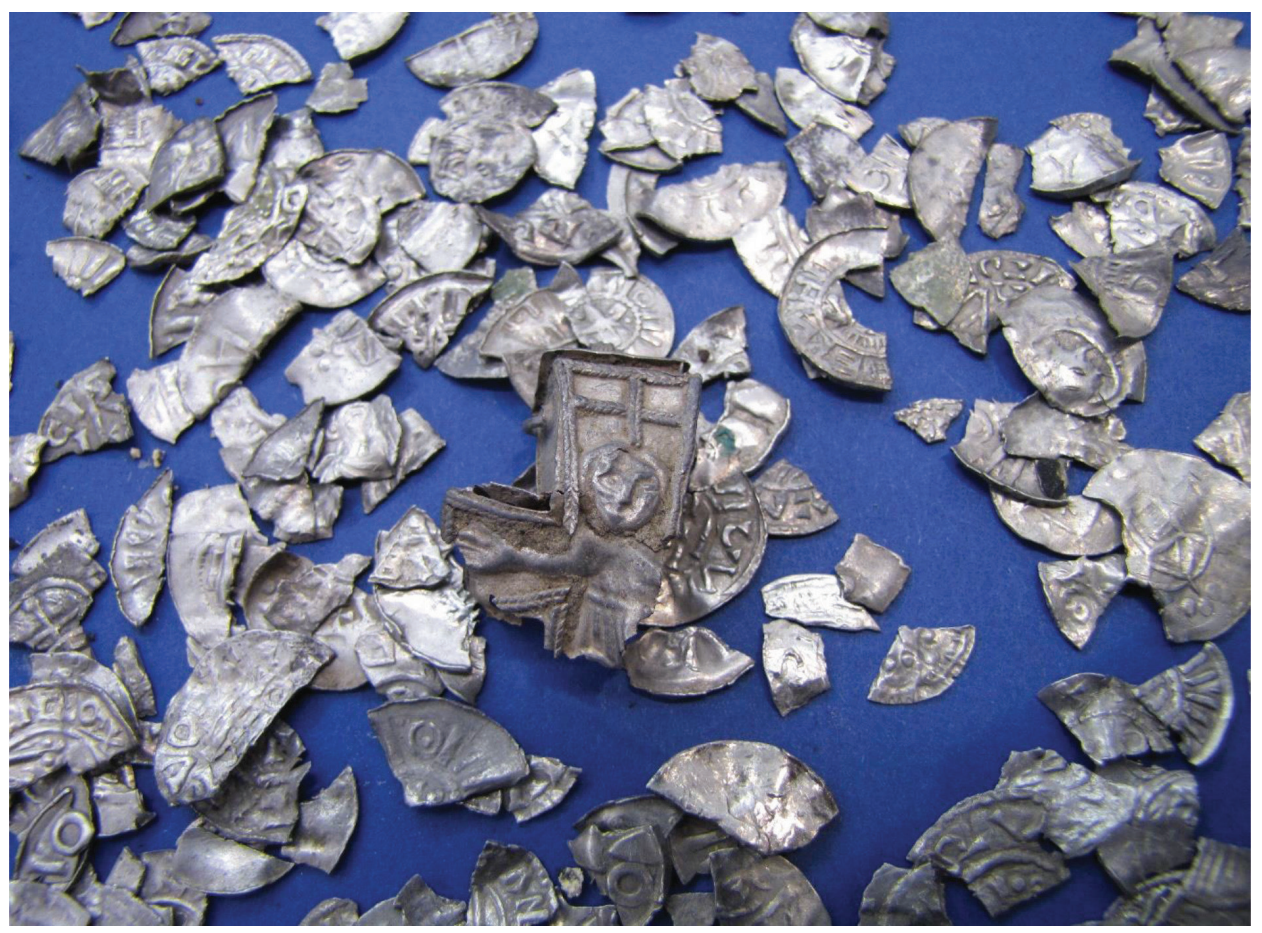

Ryc. 1. Część skarbu z Mózgowa, odkryta w 2010 roku (fot. M. Bogucki)

Kolejna część skarbu z Mózgowa została odkryta we wrześniu 2010 r. przez członków Stowarzyszenia Badaczy Historii Deutsch Eylau „Ylavia”. Analizując stare mapy i dane katastralne, członkowie stowarzyszenia natrafili na pierwsze miejsce odkrycia skarbu i przy zastosowaniu wykrywaczy metali odnaleźli w warstwie ornej łącznie 834 elementy skarbu - 717 monet i ich fragmentów oraz 117 fragmentów ozdób. Wszystkie znalezione składniku skarbu zostały przekazane do Muzeum Warmii i Mazur w Olsztynie.

Trzecia część skarbu z Mózgowa została pozyskana w trakcie regularnych badań archeologicznych prowadzonych przez Muzeum Warmii i Mazur w Olsztynie w sierpniu 2012 roku. W trakcie tych prac pozyskano łącznie 374 elementy, w tym 337 monety całe i we fragmentach oraz 37 fragmentów ozdób. W trakcie prac warstwę orną usuwano cienkimi warstwami mechanicznymi oraz przeszukiwano specjalnie dostrojonymi wykrywaczami metalu.

Porównanie monet zachowanych w Muzeum w Brunszwiku z tymi znanymi z literatury oraz odkrytymi w 2010 i 2012 r. (tabela 2) pokazuje bezsprzecznie, że monety w kolekcji brunszwickiej zostały wyselekcjonowane. Dominują monety całe oraz brakuje niemal dirhamów i ozdób. Zwraca uwagę stosunkowo niewielka liczba denarów Ottona i Adelajdy, denarów krzyżowych, monet Spiry oraz wystę- 
powanie fragmentów monet tylko w określonych grupach monet - czeskich czy angielskich. $Z$ drugiej strony widać $\mathrm{w}$ części brunszwickiej wiele monet stosunkowo rzadkich, przeważnie z Górnej i Dolnej Lotaryngii, choć tu pewną rolę odgrywa zapewne fakt, że są one reprezentowane przez monety całe, podczas gdy w częściach odkrytych w 2010 i 2012 r. dominują często niewielkie fragmenty monet, stąd wiele $\mathrm{z}$ nich jest niezmiernie trudna do identyfikacji.

Nie wchodząc w szczegóły (pełna analiza chronologii i składu skarbu z Mózgowa: patrz: Bogucki, Ilisch i Kulesza 2013, s. 14-139; Malarczyk 2013, s. 140-157; Nowakiewicz 2013, s. 158-188; Bogucki i in. 2016, s. 79-108, Nr 27), należy stwierdzić, że skarb z Mózgowa ukryto na pewno po 1009 roku. Biorąc jednak pod uwagę liczne denary krzyżowe II typu oraz denar Ottona i Adelajdy typu Hatz IV 10 m, można stwierdzić, że skarb ukryto około 1015 roku.

\section{METROLOGIA MONET EUROPEJSKICH I KWESTIA REPREZENTATYWNOŚCI DANYCH}

Skarb z Mózgowa jest typowym dla ziem polskich depozytem z początku XI wieku. Większość znajdujących się w nim monet i ozdób ukryta została we fragmentach. Depozyt ten jest dobrym przykładem do studiów metrologicznych, ponieważ dzięki różnym sposobom pozyskania monet, można uznać, że dysponujemy reprezentatywną próbką. Podobnie jak w wielu podobnych skarbach (Suchodolski 1971, s. 503-515; 2012, s. 135-139; Bogucki 2004, s. 61-62), dominują w nim fragmenty o stosunkowo niewielkiej wadze, w przedziale od 0,1 do $0,2 \mathrm{~g}$ $(18,72 \%)$. Druga kumulacja, w przedziale od 1,1 do 1,2 grama $(6,63 \%)$ odzwierciedla większą grupę monet całych. Zwraca uwagę, obserwowany w wielu innych skarbach $\mathrm{z}$ tego okresu, brak kumulacji fragmentów o wadze około 0,5-0,6 g (Bogucki 2004, s. 62). Trudno wyjaśnić na obecnym etapie badań taką strukturę wagową srebra $\mathrm{z}$ tego skarbu. Wyjaśnienie tego problemu będzie wymagało przeprowadzenia szeroko zakrojonych studiów metrologicznych na podstawie większej liczby dobrze udokumentowanych skarbów, co zdecydowanie wykracza poza ramy niniejszego opracowania. Nie mniej kluczowym warunkiem do takich studiów jest dysponowanie wiarygodną, liczną i reprezentatywną próbką materiału porównawczego. Właśnie w tym aspekcie skarb z Mózgowa, a w zasadzie historia jego odkrywania, przynosi ważne dane.

Porównanie struktury wagowej monet europejskich ze wszystkich trzech znanych części, a zatem z Muzeum w Brunszwiku oraz dwóch części pozyskanych w 2010 i 2012 r., pozwala zauważyć, że dane pochodzące ze starszej literatury oraz dane dotyczące skarbów odkrytych w czasie orki są zupełnie niemiarodajne.

Porównując strukturę wagową wszystkich trzech części (ryc. 2) można zauważyć, że wśród monet przechowywanych w muzeum w Brunszwiku dominują monety całe, z wyraźną kumujacją egzemplarzy o wadze w przedziale od 1,1 do 1,2 g $(13,31 \%)$ i cięższe (łącznie ponad $50 \%$ ). Fragmenty o wadze do $0,5 \mathrm{~g}$ stanowią 
$19 \%$, a wszystkie o wadze do $1 \mathrm{~g}, 45 \%$ zbioru. Jest to niewątpliwie wynikiem wyselekcjonowania monet do zbioru, co widoczne jest również w strukturze typologicznej.

W części odkrytej przez członków stowarzyszenia „Ilavia” na powierzchni stanowiska za pomocą wykrywaczy metali w 2010 r., zgodnie z oczekiwaniami, wyraźnie liczniejsze są drobne fragmenty monet, z kumulacją egzemplarzy w przedziale od 0,1 do $0,2 \mathrm{~g}(30,65 \%)$, natomiast monet o wadze powyżej $1 \mathrm{~g}$ jest już mniej (łącznie 16,47\%).

Sporym zaskoczeniem jest natomiast struktura wagowa fragmentów monet wydobytych podczas regularnych prac wykopaliskowych w 2012 roku. O ile można się było spodziewać, że będzie nieco mniej monet całych niż w części z 2010 r., o tyle ponad $50 \%$ udział fragmentów monet o wadzie do $0,1 \mathrm{~g}$ jest czymś zupełnie nowym. W części pozyskanej w roku 2012 fragmentów o wadze do $0,5 \mathrm{~g}$ jest $87,61 \%$, do $1 \mathrm{~g}$ jest 93,33\%, natomiast powyżej $1 \mathrm{~g}$ zaledwie 6,66\%. Tak duży odsetek bardzo małych fragmentów monet wynika wprost z zastosowanej metody wykopaliskowej - w ramach ziemi ornej kolejne warstwy mechaniczne zdejmowane były mniej więcej co 5-10 cm, powierzchnia wykopu była idealnie płaska, a wykrywacze metali były specjalnie ustawione, tak by sygnalizować nawet najsłabsze anomalie elektromagnetyczne. W efekcie pozyskano liczne, bardzo drobne fragmenty srebra, które w normalnych warunkach nie zostałyby zarejestrowane, dawały bowiem sygnały podobne do drobnych fragmentów żelaza.

$\mathrm{Z}$ powyższego porównania wynikają istotne wnioski dotyczące zarówno metodyki wykopaliskowej w przypadku skarbów siekańcowej, jak i reprezentatywności materiału źródłowego, na podstawie którego wyciągane są wnioski dotyczące metrologii wczesnośredniowecznego złomu srebrnego. Odnośnie do metodyki, to należy zauważyć, że dane dotyczące stopnia fragmentacji monet pochodzące ze starszej literatury są w zdecydowanej większości niemiarodajne (wyjątek stanowią tu skarby, które zostały odkryte in situ, najlepiej w nienaruszonym naczyniu, w trakcie prac archeologicznych). Również skarby odkrywane współcześnie przy użyciu wykrywaczy metali nie mogą stanowić w pełni wiarygodnego źródła do studiów nad metrologią siekańców, zazwyczaj bowiem wykrywacze są używane na ustawieniach fabrycznych, co powoduje, że najdrobniejsze fragmenty monet i ozdób nie są sygnalizowane, a w efekcie pozostają nieodkryte. Szczególnie dotyczy to skarbów wyoranych na polach, gdzie znajduje się sporo współczesnych śmieci żelaznych, które zagłuszają (maskują) sygnały pochodzące od przedmiotów kruszcowych. Dopiero w trakcie regularnych prac wykopaliskowych, przy zdejmowaniu cienkich warstw, przy użyciu specjalnie wyregulowanych wykrywaczy, obsługiwanych przez doświadczonych operatorów ${ }^{5}$, można pozyskać najdrobniejsze fragmen-

\footnotetext{
5 Trzeba w tym miejscu zauważyć, że niestety, zdecydowana większość zawodowych archeologów w Polsce zupełnie nie potrafi obsługiwać wykrywaczy metali. Nieliczni, którzy używają go w ramach swoich badań, i tak obsługują go na podstawowym poziomie. Zdecydowaną większość najmniejszych
} 


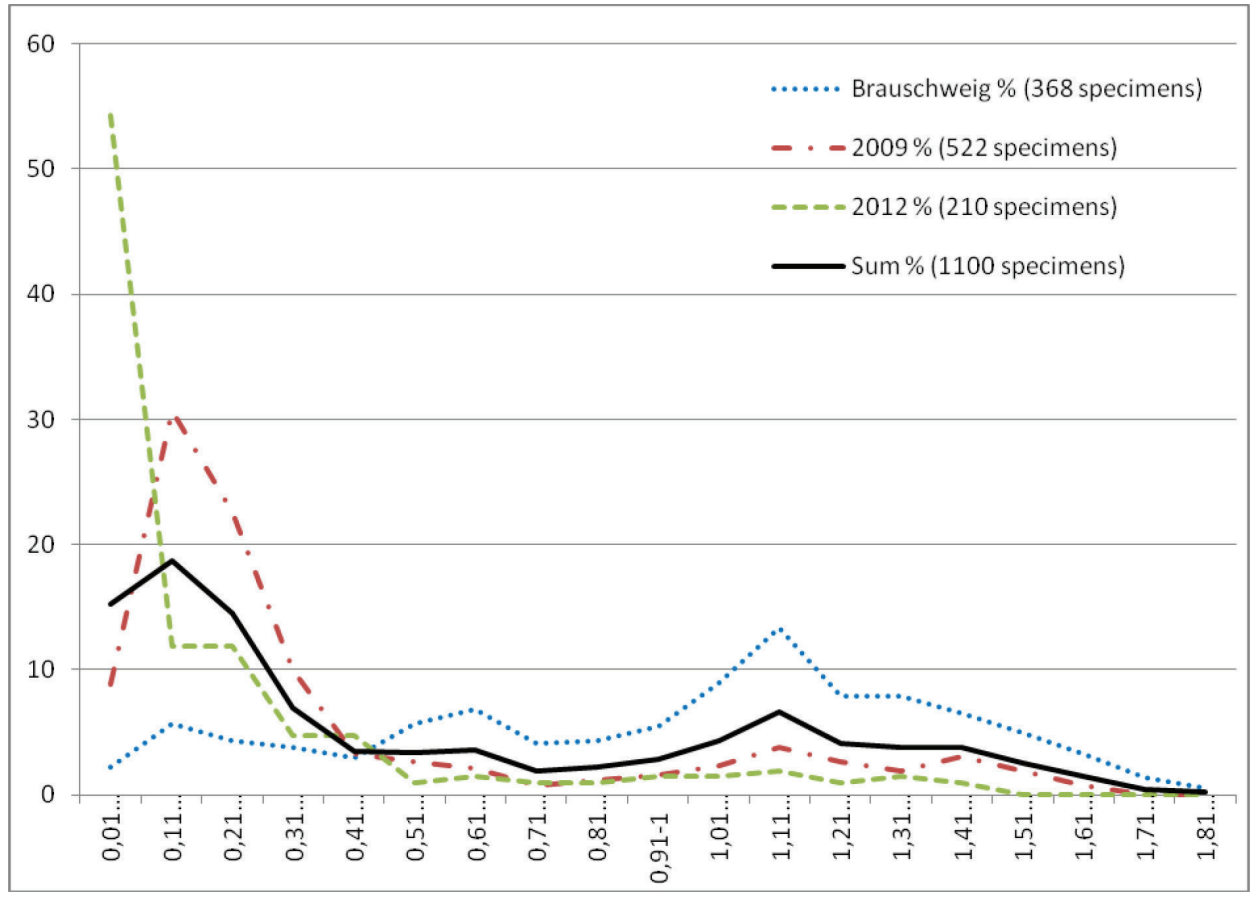

Ryc. 2. Struktura wagowa monet europejskich ze skarbu z Mózgowa. Udziały w procentach w ramach każdej części

ty zabytków, dzięki czemu pozyskane źródła będą pełniejsze, bardziej reprezentatywne i miarodajne.

\section{UWAGI KOŃCOWE}

Choć skarb z Mózgowa ujawnił niekompletność danych, które dotychczas były podstawą obliczeń statystycznych, mających na celu określenie drobnych jednostek wagowych, to niestety, sam nie dostarcza wielu nowych danych, które rozjaśniałyby kwestię ich funkcjonowania. Choć wydawać by się mogło, że zestawienie trzech znanych części skarbu z Mózgowa powinno dać statystycznie wiarygodną próbkę do badań, to porównując wykresy wagowe monet wszystkich trzech części z wykresem zbiorczym, widać, że poszczególne części odbijają się wyraźnie na końcowym wykresie. Dotyczy to zarówno wyselekcjonowanej części brunszwickiej,

fragmentów w trakcie badań w 2012 r. udało się zarejestrować tylko i wyłącznie dzięki udziałowi dwóch profesjonalnych operatorów wykrywaczy metali - Artura Troncika i Piotra Szyngiery. 
gdzie znalazły się niemal wyłącznie monety całe (stąd nieco zwiększony udział monet o wadze około $1 \mathrm{~g}$ na wykresie zbiorczym), jak i części z 2012 roku, składającej się niemal wyłącznie $\mathrm{z}$ bardzo drobnych fragmentów (stąd największy udział fragmentów poniżej $0.3 \mathrm{~g}$ ). Struktura wagowa srebra ze skarbu z Mózgowa jest zatem nietypowa - niewątpliwie brakuje w niej stosunkowo licznych fragmentów - połówek i ćwiartek, które musiały być odkryte w XIX w., ale ze względu na swoją małą atrakcyjność kolekcjonerską nie zostały włączone do kolekcji brunszwickiej i zapewne, zgodnie ze zwyczajem epoki, uległy przetopieniu. Stąd zapewne brak wyraźnej grupy ,second small unit” - fragmentów o wadze około 0.5 g. Zastrzeżenia te nie zmieniają faktu, że w skarbie z Mózgowa „first small unit”, podobnie jak na pobliskim Mazowszu, wynosi około 0.1-0.2 g (18,73\%). Nowością jest za to bardzo duży udział lżejszych fragmentów, o wadze w przedziale 0.01-0.1 g, który wynosi aż 15,27\%.

W tym miejscu należałoby się zastanowić nad funkcją, jakie te najdrobniejsze fragmenty srebra mogły ówcześnie pełnić. Oczywiście na obecnym etapie jest zbyt wcześnie na wiążące odpowiedzi - posiadamy bowiem dobrze udokumentowany tak drobny materiały tylko z jednego skarbu i nie ma pewności, czy jest on typowy, czy też nie. Nie ma jednak wątpliwości, że w skarbie z Mózgowa wystąpiły niezwykle małe i lekkie fragmenty srebrnych monet i ozdób. Część badaczy, głównie Przemysław Urbańczyk, sugerują, że małe fragmenty srebra nie mogły pełnić funkcji pieniężnych, ponieważ $\mathrm{w}$ tym czasie nie funkcjonowały jeszcze lokalne rynki wymiany towarowo-pieniężnej. P. Urbańczyk sugeruje również, że te drobne fragmenty są zbyt małe i nieporęczne, żeby mogły być używane w funkcjach pieniężnych (Urbańczyk 2002, s. 209-224; 2009, s. 501-523). Odnośnie do funkcjonowania i ewolucji lokalnych rynków wymiany we wczesnośredniowiecznej Polsce wypowiadałem się już kilkukrotnie. Ich istnienie na przełomie X i XI w. udokumentowane jest przez źródła pisane, archeologiczne i numizmatyczne (Bogucki 2004, s. 49-76; 2005, s. 1151-1157; 2011, s. 129-148; Suchodolski 2004, s. 107-116; 2013, s. 89-107 - tam starsza literatura). Odnośnie do kwestii użyteczności tak małych fragmentów srebra, wypada zauważyć, że stosowane ówcześnie wagi szalkowe są na tyle czułe, że bez problemu reagują na zmianę wagi rzędu 0.01 g. Osobiście uważam, że dominującą przyczyną fragmentaryzacji srebra we wczesnym średniowieczu była ekonomiczna potrzeba uzyskania drobnych jednostek, którymi można było dokonywać płatności. Nie można oczywiście wykluczyć innych powodów dzielenia srebra na fragmenty, ale dominowało zapotrzebowanie na małe jednostki srebra. Inną sprawą jest pytanie, czy w ówczesnych realiach były one przyjmowane na sztuki, czy też na wagę, czy też, czego nie można wykluczyć, funkcjonował system mieszany. Na obecnym etapie badań nie sposób odpowiedzieć na pytanie, czy pojawienie się licznych fragmentów ważących poniżej $0.1 \mathrm{~g}$ było wynikiem zmian wartości kruszcu, czy też wynikało z postępującego upieniężniania, gdzie coraz drobniejsze transakcje były obsługiwane za pomocą srebra. 
Łącząc dane pochodzące $\mathrm{z}$ literatury z monetami rozpoznanymi w Brunszwiku i pozyskanymi w 2010 i 2012 r., można przedstawić mniej lub bardziej szczegółową listę 1494 monet i ich fragmentów. W roku 1868 pozyskano ich co najmniej 2000 oraz jeden cały naszyjnik. Dodając do tego 1047 monet pozyskanych w roku 2010 i 2012 uzyskujemy minimalną liczbę 3047 monet. Pierwotnie musiało ich być ich jeszcze więcej, nie wiemy bowiem, ile w swojej kolekcji miał dyrektor gimnazjum Wiggert. Ostrożnie licząc, można przypuszczać, że pierwotnie skarb z Mózgowa zawierał około 4-5 tysięcy monet i ich fragmentów oraz ozdoby.

Nie znamy wagi monet odkrytych w roku 1868 , ale biorąc średnią wagę znanych monet z Brunszwiku i 2010 - czyli 0,66 g (wyłączamy tu znaleziska z 2012 r., ówcześnie bowiem nikt nie był stanie znaleźć tak drobnych fragmentów), można ocenić, że owe 2000-3000 monet ważyło około 1300-2000 gram. Nie wiadomo natomiast, ile ważył odkryty wtedy naszyjnik - można przyjąć szacunkowo, że mógł on ważyć około 100-200 g. Do tego należy dodać wagę monet i ozdób odkrytych w roku 2010 i 2012 - łącznie 406,93 g srebra (dirhemy 83,33 g + denary $282,72 \mathrm{~g}+$ ozdoby $40,99 \mathrm{~g}$ ). Zatem łączną wagę srebra ze skarbu z Mózgowa można oszacować na około 2-2,5 kg.

Powyższe wyliczenia pozwalają nam umieścić skarb z Mózgowa w grupie stosunkowo dużych depozytów wczesnośredniowiecznych. Jest to równocześnie największy wczesnośredniowieczny skarb monet odkryty na obszarze Warmii i Mazur. Istnieją od niego o wiele większe skarby w innych dzielnicach (np. wielkopolska Dzierznica, Lisówek i Słuszków, małopolskie Karczmiska czy pomorska Łupawa), ale zdecydowana większość skarbów z wczesnego średniowiecza zawiera po kilkaset monet. Jaka była ówczesna wartość srebra zdeponowanego w Mózgowie? Z powodu braku źródeł do cen towarów w X i XI w., wszelkie wyliczenia będą miały tu charakter spekulatywny, ale opierając się na dotychczasowych wynikach studiów nad wartością pieniądza w średniowieczu, można się pokusić o takie przybliżone określenie wartości. Podstawą jest tu zastosowanie miernika zwanego trofą - biologicznego wskaźnika siły nabywczej pieniądza, który określa koszt produktów potrzebnych człowiekowi do przeżycia jednego dnia (3000 kalorii). Nie znamy dokładnej wartości trofy dla XI w., ale szacuje się, że wynosiła ona około 0.2 g czystego srebra (Żabiński 1981, s. 8-15, 27-37; Suchodolski 1997, s. 151-158; 2012, s. 257-258). Z prostego przeliczenia wynika, że skarb z Mózgowa mógł mieć wartość od 10000 do 12500 trof.

\section{LITERATURA}

Albrecht G. 1959, Das Münzwesen im niederlothringischen und friesischen Raum vom 10., bis zum beginnenden 12. Jahrhundert, Hamburg, Museum für Hamburgische Geschichte.

Bahrfeldt E. 1921, Münzen des Deutschen Mittelalters, Sammlung Dr. Emil Bahrfeldt, Berlin, Frankfurt am Main: Hess.

Bergau J.N. 1868, Münzfunde aus Westpreussen, „Altpreusisiche Monatschrift” V, s. 557. 
Bogucki M. 2004, Dlaczego we wczesnym średniowieczu powstawały skarby złomu srebrnego? Uwagi na marginesie prac Jacka Kowalewskiego i Przemysława Urbańczyka, ,Wiadomości Numizmatyczne" XLVIII/1 (177), s. 49-76.

- 2005, Reasons for Hiding Early Mediaeval Hack Silver Hoards, w: C. Alfaro, C. Marcos \&

P. Otero, red., XIII Congreso Internacional de Numismática. Madrid-2003. Acta-Proceedings - Actes, Vol. 2, Madrid, Ministerio de Cultura. ss. 1151-1157.

- 2007, Coin finds in Viking Age emporium at Janów Pomorski (Truso) and the 'Prussian Phenomenon, w: S. Suchodolski, M. Bogucki, red., Money circulation in Antiquity, the Middle Ages and modern times. Time, range, intensity. International Symposium on the 50th Anniversary of Wiadomości Numizmatyczne. Warsaw, 13-14 October 2006, Warszawa-Kraków, Wydawnictwo Avalon, s. 79-108.

- 2011, The Use of Money in the Slavic Lands from the $9^{\text {th }}$ to the $11^{\text {th }}$ century - the archaeologicalnumismatic evidence, w: J. Graham-Campbell, S.M. Sindbæk i G. Williams, red., Silver Economies, Monetization and Society in Scandinavia, 800-1100, Aarhus, Aarhus University Press, s. 129-148.

- 2018, On silver fragmentation: how reliable are metrological data? A case study based on the Mózgowo hoard from Poland (t.p.q. 1009), w: J. Kershaw, G. Williams, S.M. Sindbæk i J. GrahamCampbell, red., Silver, Butter, Cloth: Monetary and Social Economies in the Viking Age, Oxford, Oxford University Press, s. 57-72.

Bogucki M., Ilisch P., Kulesza M. 2013, Monety zachodnioeuropejskie w skarbie z Mózgowa, w: E. Jelińska, red., Znaleziska średniowiecznych skarbów srebrnych z terenu Pojezierza Iławskiego w zbiorach Muzeum Warmii i Mazur, Olsztyn, Muzeum Warmii i Mazur, s. 14-139.

Bogucki M., Malarczyk D., Ilisch P., Kulesza M., Piniński J., Nowakiewicz T. 2016, Frühmittelalterliche Münzfunde aus Ermland und Masuren, w: M. Bogucki, P. Ilisch, S. Suchodolski, red., Frühmittelalterliche Münzfunde aus Polen. Inventar, Band V, Warszawa, Instytut Archeologii i Etnologii PAN. s. 19-186.

Cach F. 1970, Nejstarší české mince, Praha, Česká Numismaticka Spolěcnost.

Chmielecki K. 1907, Wykopaliska monet i srebra: Maszenice, Nieciszewo, Poczałkowo w świetle najnowszych badań, Roczniki Towarzystwa Naukowego w Toruniu 14: s. 3-44.

Czwojda L. 2007, A tentative interpretation of peck marks upon coins of the Viking Age, ,Wiadomości Numizmatyczne" LI/1 (183), s. 1-28.

Dannenberg H. 1876, Die deutschen Münzen der sächsischen und fränkischen Kaiserzeit I, Berlin, Weidmann.

- 1894, Die deutschen Münzen der sächsischen und fränkischen Kaiserzeit II, Berlin, Weidmann.

Duczko W. 2002, Test or Magic? Pecks on the Viking-Age silver, w: B. Paszkiewicz, red., Moneta Mediaevalis. Studia numizmatyczne i historyczne ofiarowane Profesorowi Stanisławowi Suchodolskiemu w 65. rocznice urodzin, Warszawa, DiG: Instytut Archeologii i Etnologii Polskiej Akademii Nauk. s. 193-208.

Eberle M. 2012, Gothas Gold - 300 Jahre Münzkabinett, Gotha, Stiftung Schloss Friedenstein.

Fiala E. 1891, Beschreibung böhmischer Münzen und Medaillen, Praha.

- 1895, Česke denary, Praha.

- 1922, Johan Etl, ,Věstník numismatickě společnosti Česko-Slovenské v Praze” IV/2, s. 181-182.

Gajewski L. i in., red. 1982, Skarby wczesnośredniowieczne z obszaru Polski. Atlas, Wrocław, Wrocław Zakład Narodowy im. Ossolińskich.

Gumowski M.1905, Wykopaliska monet polskich X i XI wieku, Kraków, nakładem Akademii Umiejętności.

- 1953, Polskie skarby monet X-XI wieku (Materiaty), Warszawa.

Hårdh B. 1996, Silver in the Viking Age. A Regional-Economic Study, Stockholm, Almqvist \& Wiksell International.

- 2008, Hacksilver and Ingots, w: D. Skre, red., Means of Exchange. Dealing with silver in the Viking Age, Kaupang Excavation Project Publication Series, vol. 2. Oslo, Aarhus University Press, s. 95-118.

Herfurth A. 1997, Mülverstedt, Johan George Adalbert von, „Neue Deutsche Biographie” 18, s. 516-517.

Ilisch L. 1990, Whole and fragmented dirhams in Near Eastern hoards. w: K. Jonnson, B. Malmer, Sigtuna Papers. Proceedings of the Sigtuna symposium on Viking-Age Coinage 1-4 June 1989, Commentationes de nummis saeculorum IX-XI, Nova Series 6, Stockholm-London, Spink, s. 121-131. 
Ilisch P. 1998, Die Münzprägung im Herzogtum Niederlothringen I: Die Münzprägung in den Räumen Utrecht und Friesland im 10. und 11. Jahrhundert, Jaarboek voor Munt- en Pfenningkunde 84-85 (1997-1998).

Jammer V. 1952, Die Anfänge der Münzprägung im Herzogtum Sachsen (10. und 11. Jahrhundert), Hamburg, Museum für Hamburgische Geschichte.

Kiersnowski R. 1956, Główne momenty rozwoju środków wymiany na Pomorzu wczesnofeudalnym, „Wiadomości Archeologiczne” XXIII, s. 229-251.

- 1960, Pieniadz kruszcowy w Polsce wczesnośredniowiecznej, Warszawa, Państwowe Wydawnictwo Naukowe.

Kiersnowscy, T. i R. 1959, Wczesnośredniowieczne skarby srebrne z Pomorza, Materiały. Polskie Skarby Wczesnośredniowieczne. Inwentarze II, Polskie Badania Archeologiczne 4. Warszawa, Zakład Narodowy im. Ossolińskich, Wydawnictwo Polskiej Akademii Nauk.

Kilger C. 2006, Silver-handling traditions during the Viking Age - Some observations and thoughts on the phenomenon of pecking and bending. w: B. Cook i G. Williams red., Coinage and History in the North Sea World c. 500-1250. Essays in Honour of Marion Archibald, Leiden, Brill. s. 449-465.

Kowalski T. 1946, Relacja Ibrahima ibn Jakuba z podróży do krajów stowiańskich w przekazie alBekriego, „Monumenta Poloniae historica”, Nova Series 1, Kraków, Gebethner i Wolff.

Kócka-Krenz H. 1993, Biżuteria pótnocno-zachodnio-stowiańska we wczesnym średniowieczu, Poznań, Wydawnictwo Naukowe Uniwersytetu im. Adama Mickiewicza.

Kujot S. 1913, Dzieje Prus Królewskich, Vol. I, „Roczniki Towarzystwa Naukowego w Toruniu” 20.

La Baume W. 1938, Die Silberhortfunde des frühen Mittelalters aus dem Gebiet an der unteren Weichsel, „Altpreussische Forschungen” 15, s. 42-62.

Langenheim K. 1933, Spuren der Wikinger um Truso, „Elbinger Jahrbuch” 11, s. 262-264.

Łęga W. 1930, Kultura Pomorza we wczesnym średniowieczu na podstawie wykopalisk, Toruń, Towarzystwo Naukowe.

Łosiński W. 1988, Chronologia napływu najstarszej monety arabskiej na terytorium Europy, „Slavia Antiqua" 31, s. 93-181.

Malarczyk D. 2013, Monety arabskie w skarbie z Mózgowa, w: E. Jelińska, red., Znaleziska średniowiecznych skarbów srebrnych z terenu Pojezierza Itawskiego w zbiorach Muzeum Warmii i Mazur, edited by Olsztyn, Muzeum Warmii i Mazur, s. 140-157.

Malmer B. 1966, Nordiska mynt före år 1000. Bonn/Lund: Habelt/Gleerup.

Markov A. 1910, Topografija kładov vostočnykh monet, St. Petersburg.

Moesgaard J.Ch. 2015, King Harald's Cross Coinage. Christian Coins for the Merchants of Haithabu and the King's Soldiers. Studies in Archaeology \& History, vol. 20:2 Jelling Series, Copenhagen, National Museum of Denmark.

Nowakiewicz T. 2003, Ozdoby i srebro siekane z wczesnośredniowiecznego skarbu srebrnego z Ciechanowa, w: W. Wróblewski, red., Studia Galindzkie I, Warszawa, Instytut Archeologii Uniwersytet Warszawski, s. 261-318.

- 2013, Niemonetarna część skarbu z Mózgowa, w: E. Jelińska, red., Znaleziska średniowiecznych skarbów srebrnych z terenu Pojezierza Itawskiego w zbiorach Muzeum Warmii i Mazur, edited by Olsztyn, Muzeum Warmii i Mazur, s. 158-188.

Suchodolski S. 1971, W sprawie intensywności wymiany lokalnej na ziemiach polskich w X-XI wieku, „Archeologia Polski” XVI, s. 503-515.

- 1997, Zasoby pieniężne ,, szarego czlowieka” w Polsce wczesnośredniowiecznej, w: R. Michałowski, red., Człowiek w spoleczeństwie średniowiecznym, Warszawa, Wydawnictwo DiG, s. 151-158.

- 2004, Aus welchen Gründen hat man in der Wikingerzeit im Ostseeraum Münzschätze deponiert?. w: R. Cunz red., Fundamenta Historiae. Geschichte im Spiegel der Numismatik und ihrer Nachbarwissenschaften. Festschrift für Niklot Klüßendorf zum 60. Geburtstag am 10. Februar 2004, Hannover, Schmidt, s. 107-116.

- 2012, Numizmatyka średniowieczna. Moneta źródłem archeologicznym, historycznym i ikonograficznym, Warszawa, Wydawnictwo Trio.

- 2013, Warum hat man im frühen Mittelalter Schätze deponiert?, w: M. Bogucki, M. Rębkowski, red., Economies, Monetisation and Society in West Slavic Lands 800-1200 AD, Wolińskie Spotka- 
nia Mediewistyczne II. Szczecin, Instytut Archeologii i Etnologii, Polskiej Akademii Nauk, s. $89-107$.

Suhle A. 1926, Angelsächsische Münzen in den grösseren Schatzfunden östlich der Elbe von ca. 950 bis ca. 1150 n. C., Blätter für Münzfreunde III/1, s. 80

- 1928, Angelsächsische Münzen in nordostdeutsche Funden, „Blätter für Münzfreunde” 63/3: s. 225-230.

Tambor J. 1989, Pieniężne funkcje biżuterii srebrnej na ziemiach polskich w X-XI wieku, „Wiadomości Numizmatyczne" 23 (127-130), s. 12-43.

Urbańczyk P. 2002, Wczesnośredniowieczne skarby złomu srebrnego, w: B. Paszkiewicz, red., Moneta Mediaevalis. Studia numizmatyczne i historyczne ofiarowane Profesorowi Stanistawowi Suchodolskiemu w 65. rocznicę urodzin, Warszawa, Wydawnictwo DiG, Instytut Archeologii i Etnologii, Polskiej Akademii Nauk. s. 209-224.

- 2009, The Polish discussion on medieval deposits of hack-silver, w: S. Brather, D. Guenich i C. Huth, red., Historia archaeologica, Berlin-New York, De Gruyter. s. 501-523.

Żabiński Z. 1981, Systemy pieniężne na ziemiach polskich, Kraków, Zakład Narodowy im. Ossolińskich. Żak J. 1963, „Importy” skandynawskie na ziemiach zachodniostowiańskich od IX do XI w. 1. Katalog, Poznań, Państwowe Wydawnictwo Naukowe. 